\title{
Gloss of thermally densified alder (Alnus glutinosa Goertn.), beech (Fagus sylvatica L.), birch (Betula verrucosa Ehrh.), and pine (Pinus sylvestris $\mathbf{L}$.) wood veneers
}

\author{
Pavlo Bekhta $\cdot$ Stanisław Proszyk $\cdot$ Barbara Lis $\cdot$ \\ Tomasz Krystofiak
}

Received: 2 April 2014/Published online: 10 October 2014

(C) The Author(s) 2014. This article is published with open access at Springerlink.com

\begin{abstract}
Thermo-mechanical densification of wood is performed to improve physical and mechanical properties of wood. During this treatment aesthetic properties of wood, including gloss, also change. Therefore, the purpose of this study was to determine the effect of short-term thermo-mechanical (STTM) densification in different wood species (alder (Alnus glutinosa Goertn.), beech (Fagus sylvatica L.), birch (Betula verrucosa Ehrh.), and pine (Pinus sylvestris L.)) on their gloss changes. Commercial wood veneers were densified in a hot plate press for $4 \mathrm{~min}$ at temperatures of 100,150 and $200{ }^{\circ} \mathrm{C}$, pressures of 4,8 and $12 \mathrm{MPa}$. Gloss was evaluated at $20^{\circ}, 60^{\circ}$ and $85^{\circ}$ angles of incident light using PICO GLOSS 503. Gloss measurements showed an enhancement of aesthetic properties of densified wood. Findings of this study indicated that both densification temperature and pressure have a significant effect on wood gloss. Gloss values of densified wood increased with increasing densification temperature and pressure for all investigated species. Compared to nondensified wood, gloss $\left(85^{\circ}\right)$ values (across/along the grain) for alder, beech, birch and pine increased after treatment to 2109.1/2376.9, 1728.6/2311.1, 2787.5/3000, and 2591.7/ $1216.7 \%$, respectively. The greatest gloss values were recorded at $200{ }^{\circ} \mathrm{C}$ and pressure of $12 \mathrm{MPa}$ for all tested angles of incident light and for all densified wood samples. Gloss changes for birch were the highest, but the glossiest
\end{abstract}

\section{P. Bekhta $(\bowtie)$}

Department of Wood-Based Composites, National University of Forestry and Wood Technology of Ukraine, 79057 Lviv, Ukraine e-mail: bekhta@ukr.net

S. Proszyk - B. Lis - T. Krystofiak

Department of Gluing and Finishing of Wood, Poznan

University of Life Sciences, 60637 Poznan, Poland surface was observed for pine among all investigated species after wood densification.

\section{Introduction}

Wood has been widely and popularly used as a decorative material because of its aesthetic appearance and characteristics properties. However, wood is much easier destroyed by environmental factors, including water, light, fire and living organisms, than many other man-made materials (Wood handbook 2010). Therefore, in recent years there has been a rapid increase in the application of different modification methods to wood and wood materials in order to improve their properties. In particular, thermal, thermo-mechanical and thermo-hydro-mechanical treatments of wood have been widely studied and applied to improve its properties (Bekhta et al. 2012; Candan et al. 2013; Diouf et al. 2011; Fang et al. 2012; Kamke 2006; Korkut et al. 2013; Kutnar and Šernek 2007; Militz 2002; Navi and Girardet 2000; Navi and Sandberg 2012; Tarkow and Seborg 1968; Welzbacher et al. 2008). This treatment alters both chemical and physical properties of wood. Heattreated wood exhibits new characteristics such as reduced water absorption, improved dimensional stability, better resistance to destruction by insects and microorganisms. However, perhaps the most important change of heattreated wood is its aesthetic appearance. Such wood is characterized by an attractive darker color (Bekhta and Niemz 2003; Gonzalez-Pena and Hale 2009). The new versatile properties and attractive darker color make heattreated wood popular for different applications. However, exterior appearance of wood is estimated not only by its color and roughness, but also by gloss. Gloss is a unique wood texture attribute compared to texture of other 
materials. Gloss plays the most important role in the appearance of different materials and is an important consumer feature. There is an extensive body of information in respect of changes in color and surface roughness of heat-treated wood (Akgul and Korkut 2012; Bekhta and Niemz 2003; Candan et al. 2010; Diouf et al. 2011; Dundar et al. 2008; Gonzalez-Pena and Hale 2009; Korkut et al. 2013; Sundqvist 2002). In contrast, there is very limited information concerning gloss of wood (Kato and Masuda 1989; Masuda et al. 1989; Nakamura et al. 1999). Still it can be assumed that not only color and surface roughness but also gloss is changed during thermo-mechanical treatment of wood.

Previous studies investigated the effect of heat treatment (Aksoy et al. 2011; Cakicier et al. 2011b; Korkut et al. 2013; Shaoping et al. 2010), impregnation process (Simsek and Baysal 2012) and coatings of wood (Demirci et al. 2013; Goktas and Toker 2010; Scrinzi et al. 2011; Sönmez et al. 2004) on the changes in color and gloss of treated and finished wood samples. Nakamura et al. (1999) developed and used two digital-image analyzing methods (multi resolutional contrast analysis and fractal analysis) to express wood gloss quantitatively. Visual characteristics of gloss of materials were demonstrated quantitatively using numerical indices for the frequency and magnitude of brightness variation in the image.

Simsek and Baysal (2012) examined the effects of the impregnation process with $3 \%$ aqueous borate solution on changes in color and gloss values of beech and pine wood samples. Borate treatments remarkably decreased gloss values in Oriental beech (by 28-37 \%) and Scots pine (by 32-45\%). Aksoy et al. (2011) found that heat treatment in an oven for 2,4 , and $8 \mathrm{~h}$ at 150,175 , and $200{ }^{\circ} \mathrm{C}$ decreased to some extent gloss values of Scots pine (Pinus sylvestris L.) wood samples. Gloss values of Scots pine decreased by $5.5-36.6 \%$ after heat treatment. In general, gloss values of heat-treated Scots pine samples decreased with increasing treatment duration and temperature. Korkut et al. (2013) evaluated the effect of heat treatment on surface properties of wild cherry (Prunus avium) including surface roughness, gloss, and color stability. Gloss and surface roughness values of the samples decreased with heat treatment (temperature of $212{ }^{\circ} \mathrm{C}$ for 1.5 and $2.5 \mathrm{~h}$ ) compared to those of control samples. Gloss changes were the most pronounced at the end of the exposure. These results are in accordance with the findings of some experiments conducted earlier (Cakicier et al. 2011b). Cakicier et al. (2011a) found that gloss of varnished samples after heat treatment was higher than that of varnished untreated samples. Gloss increased in wood samples for all of the four wood species treated with cellulose lacquer and synthetic varnish and across all heat treatments (150 and $180^{\circ} \mathrm{C}$ ). However, gloss values were decreased for all the wood species depending on heating temperature and time. Demirci et al. (2013) investigated the effect of thermal ageing of several wood varnishes on film characteristics. Samples of 8 or $12 \%$ moisture content were thermally aged for $25,50,75$, and 100 days at $25,50,75$, and $100{ }^{\circ} \mathrm{C}$. The results of the study indicated that thermal ageing caused a decrease in adhesion strength and gloss values. An increase in moisture content of the wood material resulted in deterioration of gloss in the conducted study.

A literature review showed that there is a lack of scientific results concerning gloss of wood thermo-mechanically densified at different temperatures and pressures. Therefore, the main objective of this study was to obtain initial data on gloss of different thermo-mechanically densified wood species so that such species can be used more effectively and efficiently to produce value-added products.

\section{Materials and methods}

\subsection{Materials}

Commercial rotary cut veneer sheets were obtained from alder (Alnus glutinosa Goertn.), beech (Fagus sylvatica L.), birch (Betula verrucosa Ehrh.) and pine (Pinus sylvestris L.) $\operatorname{logs}$ at the Sklejka-Multi S.A. plywood company in Bydgoszcz, Poland. Defect-free veneer sheets of $300 \times 300 \times 1.5 \mathrm{~mm}^{3}$ with $5 \%$ moisture were then transported to the laboratory. Tangential sheets of veneer were cut into $140 \times 100 \mathrm{~mm}^{2}$ rectangular pieces for the thermo-mechanical densification process and subsequent measurements. Prior to thermo-mechanical densification, all test samples were equilibrated at a temperature of $20{ }^{\circ} \mathrm{C}$ and relative humidity of $65 \%$.

\subsection{Short-term thermo-mechanical densification technique}

Short-term thermo-mechanical (STTM) densification was performed using a temperature-controlled laboratory press. Three different densification temperatures $(100,150$, and $200{ }^{\circ} \mathrm{C}$ ) and three densification pressures (4, 8, and $12 \mathrm{MPa}$ ) were applied to wood samples. Each wood sample was thermo-mechanically densified for 4 min between smooth and thoroughly cleaned heated plates of the press at applied temperatures and pressures.

\subsection{Gloss measurement}

Changes in properties of densified surface veneer were evaluated by gloss measurements. Gloss is an optical phenomenon related to the appearance of a surface and 
represents the capacity of a surface to reflect directed light (ASTM D523 1995). Gloss is considered to be the proportion of incident light that is reflected at the specular reflectance angle (with respect to the normal plane of the surface). Gloss was determined according to DIN 67530 (1982), ISO 2813 (1994) using a PICO GLOSS 503

Table 1 Gloss values of non-densified and densified veneer surfaces measured at different angles

\begin{tabular}{|c|c|c|c|c|c|c|c|}
\hline \multicolumn{2}{|c|}{ Densification parameters } & \multicolumn{6}{|c|}{ Angle of incidence $\left(^{\circ}\right)$} \\
\hline \multirow[t]{2}{*}{ Temperature $\left({ }^{\circ} \mathrm{C}\right)$} & \multirow[t]{2}{*}{ Pressure (MPa) } & \multicolumn{3}{|c|}{ Gloss measured across $(\perp)$ the grain } & \multicolumn{3}{|c|}{ Gloss measured along $(\|)$ the grain } \\
\hline & & 20 & 60 & 85 & 20 & 60 & 85 \\
\hline \multirow{4}{*}{$\begin{array}{l}\text { Alder non-densified } \\
100\end{array}$} & & $1.1(0.0)$ & $2.9(0.1)$ & $1.1(0.0)$ & $1.2(0.1)$ & $4.2(0.3)$ & $1.3(0.2)$ \\
\hline & 4 & $1.1(0.0)$ & $3.9(0.2)$ & $5.2(0.4)$ & $1.2(0.0)$ & $5.4(0.2)$ & $10.5(1.1)$ \\
\hline & 8 & $1.2(0.0)$ & $4.5(0.1)$ & $5.7(0.2)$ & $1.3(0.0)$ & $6.0(0.2)$ & $12.6(0.5)$ \\
\hline & 12 & $1.2(0.1)$ & $5.1(0.2)$ & $5.7(0.4)$ & $1.3(0.0)$ & $6.6(0.2)$ & $14.2(0.9)$ \\
\hline \multirow[t]{3}{*}{150} & 4 & $1.1(0.0)$ & $4.5(0.2)$ & $7.3(1.6)$ & $1.2(0.1)$ & $6.4(0.3)$ & $16.9(0.8)$ \\
\hline & 8 & $1.3(0.0)$ & $5.5(0.1)$ & $10.8(0.8)$ & $1.4(0.1)$ & $7.9(0.3)$ & $18.1(0.8)$ \\
\hline & 12 & $1.3(0.0)$ & $5.4(0.2)$ & $8.2(0.7)$ & $1.4(0.1)$ & $7.5(0.4)$ & $16.4(0.9)$ \\
\hline \multirow[t]{3}{*}{200} & 4 & $1.1(0.1)$ & $4.9(0.3)$ & $12.0(1.4)$ & $1.2(0.1)$ & $7.5(0.5)$ & $21.2(2.0)$ \\
\hline & 8 & $1.2(0.1)$ & $7.0(0.6)$ & $23.8(2.3)$ & $1.4(0.1)$ & $10.7(0.4)$ & $31.5(1.2)$ \\
\hline & 12 & $1.5(0.1)$ & $8.3(0.2)$ & $24.3(1.2)$ & $1.7(0.1)$ & $12.3(0.4)$ & $32.2(1.3)$ \\
\hline \multicolumn{2}{|l|}{ Beech non-densified } & $0.9(0.0)$ & $2.0(0.0)$ & $0.7(0.1)$ & $0.9(0.0)$ & $3.2(0.0)$ & $0.9(0.1)$ \\
\hline \multirow[t]{3}{*}{100} & 4 & $0.9(0.0)$ & $2.8(0.1)$ & $3.3(0.3)$ & $1.1(0.0)$ & $4.0(0.2)$ & $5.5(1.1)$ \\
\hline & 8 & $1.0(0.0)$ & $3.5(0.1)$ & $5.4(0.5)$ & $1.1(0.1)$ & $4.5(0.1)$ & $8.9(0.7)$ \\
\hline & 12 & $1.1(0.0)$ & $4.0(0.1)$ & $5.5(0.2)$ & $1.1(0.0)$ & $4.7(0.3)$ & $12.0(0.7)$ \\
\hline \multirow[t]{3}{*}{150} & 4 & $1.0(0.0)$ & $3.2(0.1)$ & $4.8(0.4)$ & $1.0(0.0)$ & $4.2(0.1)$ & $7.3(0.8)$ \\
\hline & 8 & $1.1(0.0)$ & $4.1(0.1)$ & $8.1(0.2)$ & $1.1(0.0)$ & $5.5(0.1)$ & $12.7(0.5)$ \\
\hline & 12 & $1.1(0.0)$ & $4.2(0.1)$ & $7.4(0.3)$ & $1.1(0.0)$ & $5.5(0.1)$ & $14.1(0.5)$ \\
\hline \multirow[t]{3}{*}{200} & 4 & $0.7(0.0)$ & $3.3(0.1)$ & $7.9(0.7)$ & $0.8(0.1)$ & $4.7(0.2)$ & $13.9(1.0)$ \\
\hline & 8 & $0.9(0.1)$ & $4.4(0.2)$ & $8.8(0.3)$ & $0.9(0.0)$ & $6.0(0.3)$ & $17.3(1.2)$ \\
\hline & 12 & $1.0(0.1)$ & $5.3(0.2)$ & $12.8(1.0)$ & $1.0(0.1)$ & $6.8(0.4)$ & $21.7(1.3)$ \\
\hline \multicolumn{2}{|l|}{ Birch non-densified } & $0.9(0.0)$ & $2.5(0.0)$ & $0.8(0.0)$ & $1.0(0.0)$ & $3.7(0.1)$ & $1.2(0.1)$ \\
\hline \multirow[t]{3}{*}{100} & 4 & $1.4(0.0)$ & $4.3(0.1)$ & $4.2(0.2)$ & $1.5(0.0)$ & $6.2(0.3)$ & $7.7(1.0)$ \\
\hline & 8 & $1.5(0.1)$ & $5.5(0.1)$ & $5.8(0.8)$ & $1.6(0.1)$ & $7.3(0.4)$ & $14.7(0.9)$ \\
\hline & 12 & $1.5(0.1)$ & $5.8(0.2)$ & $6.7(1.0)$ & $1.7(0.0)$ & $8.3(0.4)$ & $17.3(1.1)$ \\
\hline \multirow[t]{3}{*}{150} & 4 & $1.3(0.0)$ & $4.5(0.1)$ & $7.8(0.6)$ & $1.5(0.0)$ & $7.0(0.3)$ & $12.7(1.0)$ \\
\hline & 8 & $1.6(0.1)$ & $6.3(0.2)$ & $13.9(1.0)$ & $1.7(0.1)$ & $9.1(0.5)$ & $20.4(2.1)$ \\
\hline & 12 & $1.7(0.1)$ & $6.8(0.2)$ & $17.2(1.4)$ & $1.9(0.1)$ & $10.2(0.5)$ & $25.7(1.5)$ \\
\hline \multirow[t]{3}{*}{200} & 4 & $1.2(0.1)$ & $5.1(0.4)$ & $12.1(0.9)$ & $1.3(0.1)$ & $8.0(0.4)$ & $19.4(1.6)$ \\
\hline & 8 & $1.2(0.1)$ & $6.5(0.3)$ & $15.8(1.2)$ & $1.4(0.1)$ & $9.9(0.5)$ & $24.7(1.3)$ \\
\hline & 12 & $1.7(0.1)$ & $8.5(0.2)$ & $23.1(2.2)$ & $1.9(0.1)$ & $13.6(0.3)$ & $37.2(1.4)$ \\
\hline \multicolumn{2}{|l|}{ Pine non-densified } & $1.3(0.1)$ & $4.3(0.2)$ & $1.2(0.1)$ & $1.5(0.1)$ & $6.6(0.4)$ & $3.0(0.6)$ \\
\hline \multirow[t]{3}{*}{100} & 4 & $1.6(0.1)$ & $6.7(0.2)$ & $9.0(0.5)$ & $1.8(0.1)$ & $9.8(0.5)$ & $18.6(1.4)$ \\
\hline & 8 & $1.7(0.0)$ & $7.4(0.3)$ & $7.6(0.9)$ & $1.9(0.1)$ & $10.5(0.6)$ & $17.9(2.3)$ \\
\hline & 12 & $1.8(0.1)$ & $7.8(0.4)$ & $9.6(0.7)$ & $1.8(0.1)$ & $10.0(0.4)$ & $18.3(0.8)$ \\
\hline \multirow[t]{3}{*}{150} & 4 & $1.6(0.1)$ & $6.6(0.1)$ & $10.3(1.0)$ & $1.8(0.1)$ & $9.9(0.5)$ & $19.3(1.7)$ \\
\hline & 8 & $1.9(0.1)$ & $8.7(0.5)$ & $18.7(1.3)$ & $2.1(0.1)$ & $13.0(0.5)$ & $27.5(2.0)$ \\
\hline & 12 & $1.7(0.1)$ & $8.3(0.3)$ & $21.5(1.2)$ & $1.9(0.2)$ & $11.9(0.8)$ & 29.8 \\
\hline \multirow[t]{3}{*}{200} & 4 & $1.6(0.2)$ & $7.9(0.6)$ & $21.4(2.2)$ & $1.7(0.1)$ & $11.0(0.7)$ & $27.1(4.0)$ \\
\hline & 8 & $1.6(0.1)$ & $8.9(0.8)$ & $29.4(2.5)$ & $1.8(0.1)$ & $13.3(1.2)$ & $35.3(2.3)$ \\
\hline & 12 & $2.2(0.1)$ & $11.5(0.4)$ & $32.3(1.8)$ & $2.3(0.1)$ & $16.3(0.7)$ & $39.5(2.2)$ \\
\hline
\end{tabular}

Values in parenthesis are standard deviations based on twelve samples 
Table 2 Changes in gloss after thermo-mechanical densification

\begin{tabular}{|c|c|c|c|c|}
\hline \multirow[t]{2}{*}{ Wood species } & \multirow[t]{2}{*}{ Angle of incident light $\left({ }^{\circ}\right)$} & \multicolumn{2}{|l|}{ Gloss values } & \multirow{2}{*}{$\begin{array}{l}\text { Reduction }(-) \text { or increase }(+) \text { in } \\
\text { gloss after densification }(\%)\end{array}$} \\
\hline & & Before densification & $\begin{array}{l}\text { After densification at } 100{ }^{\circ} \mathrm{C} \text {, } \\
4 \mathrm{MPa} / 200{ }^{\circ} \mathrm{C}, 12 \mathrm{MPa}\end{array}$ & \\
\hline \multirow[t]{6}{*}{ Alder } & $20(\|)$ & 1.2 & $1.2 / 1.7$ & $0.0 /+41.7$ \\
\hline & $20(\perp)$ & 1.1 & $1.1 / 1.5$ & $0.0 /+36.4$ \\
\hline & $60(\|)$ & 4.2 & $5.4 / 12.3$ & $+28.6 /+192.9$ \\
\hline & $60(\perp)$ & 2.9 & $3.9 / 8.3$ & $+34.5 /+186.2$ \\
\hline & $85(\|)$ & 1.3 & $10.5 / 32.2$ & $+707.7 /+2376.9$ \\
\hline & $85(\perp)$ & 1.1 & $5.2 / 24.3$ & $+372.7 /+2109.1$ \\
\hline \multirow[t]{6}{*}{ Beech } & $20(\|)$ & 0.9 & $1.1 / 1.0$ & $+22.2 /+11.1$ \\
\hline & $20(\perp)$ & 0.9 & $0.9 / 1.0$ & $0.0 /+11.1$ \\
\hline & $60(\|)$ & 3.2 & $4.0 / 6.8$ & $+25.0 /+112.5$ \\
\hline & $60(\perp)$ & 2.0 & $2.8 / 5.3$ & $+40.0 /+65.0$ \\
\hline & $85(\|)$ & 0.9 & $5.5 / 21.7$ & $+511.1 /+2311.1$ \\
\hline & $85(\perp)$ & 0.7 & $3.3 / 12.8$ & $+371.4 /+1728.6$ \\
\hline \multirow[t]{6}{*}{ Birch } & $20(\|)$ & 1.0 & $1.0 / 1.9$ & $+50.0 /+90.0$ \\
\hline & $20(\perp)$ & 0.9 & $0.9 / 1.7$ & $+55.6 /+88.9$ \\
\hline & $60(\|)$ & 3.7 & $3.7 / 13.6$ & $+67.6 /+267.6$ \\
\hline & $60(\perp)$ & 2.5 & $2.5 / 8.5$ & $+72.0 /+240.0$ \\
\hline & $85(\|)$ & 1.2 & $1.2 / 37.2$ & $+541.7 /+3,000$ \\
\hline & $85(\perp)$ & 0.8 & $0.8 / 23.1$ & $+425.0 /+2787.5$ \\
\hline \multirow[t]{6}{*}{ Pine } & $20(\|)$ & 1.5 & $1.5 / 2.3$ & $+20.0 /+53.3$ \\
\hline & $20(\perp)$ & 1.3 & $1.3 / 2.2$ & $+23.1 /+69.2$ \\
\hline & $60(\|)$ & 6.6 & $6.6 / 16.3$ & $+48.5 /+147.0$ \\
\hline & $60(\perp)$ & 4.3 & $4.3 / 11.5$ & $+55.8 /+167.4$ \\
\hline & $85(\|)$ & 3.0 & $3.0 / 39.5$ & $+520.0 /+1216.7$ \\
\hline & $85(\perp)$ & 1.2 & $1.2 / 32.3$ & $+650.0 /+2591.7$ \\
\hline
\end{tabular}

photoelectric apparatus. Surface gloss of non-densified and densified veneer surface was measured at $20^{\circ}, 60^{\circ}$ and $85^{\circ}$ angles of incident light. Two measurements were taken from the surface of each sample, one along $(\|)$ and one across $(\perp)$ the grain. Complete specular light reflection, which is perfect gloss, would be $100 \%$, and complete diffuse light reflection matt would be $0 \%$.

\subsection{Scanning electron microscopy (SEM) analysis}

In order to highlight the morphology of the densified surface and correlate it to gloss changes, densified surfaces were examined using scanning electron microscopy (VEGA TS 5130).

\subsection{Statistical analysis}

Veneers from four different wood species (alder, beech, birch, and pine), three different densification temperatures $\left(100,150\right.$, and $\left.200^{\circ} \mathrm{C}\right)$, three different densification pressures $(4,8$, and $12 \mathrm{MPa})$, three different angles $\left(20^{\circ}, 60^{\circ}\right.$, $85^{\circ}$ ), two directions of measurement (along and across the grain), and twelve replications for each cell were prepared $(4 \times 3 \times 3 \times 3 \times 2 \times 12=2,592$ samples $)$. A full factorial analysis of variance was conducted in order to determine the effects of each dependent variable. In cases where the differences between the groups were statistically significant, a comparison was made with Duncan's multiple range test at the $\alpha=0.05$ confidence level.

\section{Results and discussion}

Gloss measurements quantified improvement of aesthetic properties. Average gloss values of all investigated wood species are given in Table 1. Among all samples, the highest gloss value was obtained for pine veneers and the lowest value was recorded for beech veneers.

Changes in the percentage of gloss values of densified veneer compared with non-densified veneer are shown in Table 2. It was found that short-term thermo-mechanical densification causes a considerable increase, in comparison 
Fig. 1 Average gloss values of wood species at different angles of incidence: $\mathbf{a}$ in non-densified wood veneer; $\mathbf{b}$ in wood veneer densified at $200{ }^{\circ} \mathrm{C}$ and $12 \mathrm{MPa}$
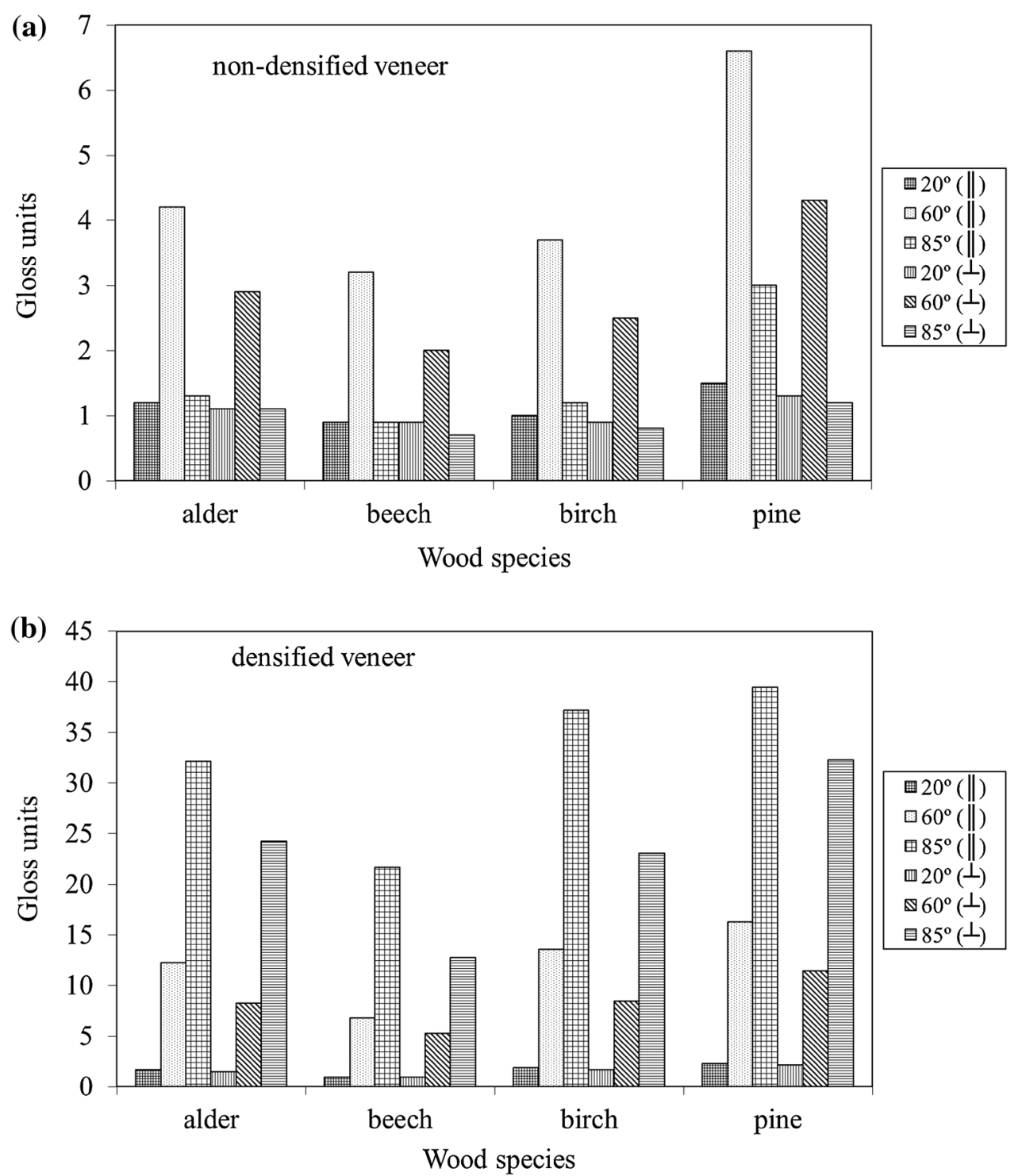

with non-densified veneer, of gloss values measured at different angles of incident light with increasing temperature and pressure of densification. For example, gloss $\left(85^{\circ}\right)$ values (across/along the grain) for alder, beech, birch and pine increased after treatment to 2109.1/2376.9, 1728.6/ $2311.1,2787.5 / 3000$, and $2591.7 / 1216.7 \%$, respectively compared to non-densified wood. The reason for the increase in gloss at higher densification temperature and pressure probably comes from the smaller light scattering of increasingly smoother veneer surfaces. Non-densified veneer samples presented lower gloss (they were matt surfaces) than veneer densified at different temperatures and pressures (they were half-matt surfaces).

Figure 1 presents gloss values at three angles. For nondensified wood with an increasing angle of incidence the specular reflectance initially increases, but at angles over $60^{\circ}$ it rapidly subsides (Fig. 1a). Herewith, diffuse reflection drops. Gloss values obtained at angles of 20 and $85^{\circ}$ are practically identical. The latter is probably due to the very high roughness value of non-densified (original) veneer surface. The presence of surface irregularities diminishes the measured value of gloss, especially at higher angles. For densified wood the specular reflectance increases with an increasing angle of incidence from $20^{\circ}$ to $85^{\circ}$ (Fig. 1b). Obviously, the natural characteristics of wood have an influence on surface roughness and consequently on gloss properties. As it can be seen from Fig. 1, the effect of roughness on gloss at $20^{\circ}$ and $85^{\circ}$ appears stronger for non-densified wood than for densified wood. ESEM observations (Fig. 2) allowed highlighting the different morphology of the non-densified and densified surfaces. The reason for the decreasing glossiness at higher roughness values probably comes from the larger light scattering on increasingly more irregular and complex 
Fig. 2 SEM images on

longitudinal tangential surfaces of samples before and after densification: a non-densified alder veneer; $\mathbf{b}$ alder veneer densified at $200{ }^{\circ} \mathrm{C}$ and $12 \mathrm{MPa}$; non-densified beech veneer; $\mathbf{d}$ beech veneer densified at $200{ }^{\circ} \mathrm{C}$ and $12 \mathrm{MPa}$; e non-densified birch veneer; $\mathbf{f}$ birch veneer densified at $200{ }^{\circ} \mathrm{C}$ and $12 \mathrm{MPa}$; $\mathrm{g}$ nondensified pine veneer; $\mathbf{h}$ pine veneer densified at $200{ }^{\circ} \mathrm{C}$ and $12 \mathrm{MPa}$ (a)

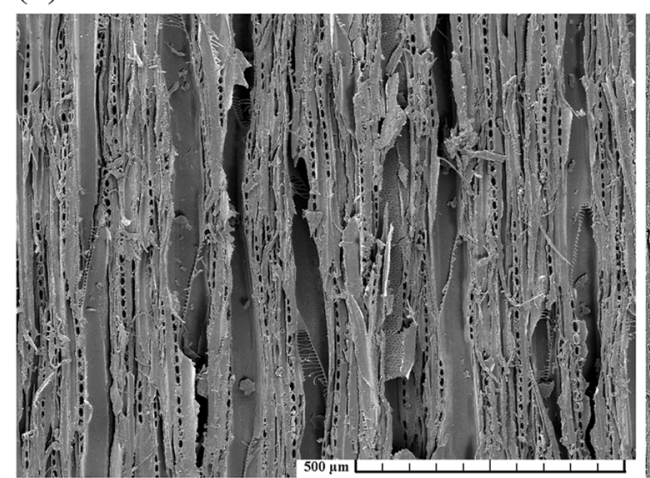

(c)

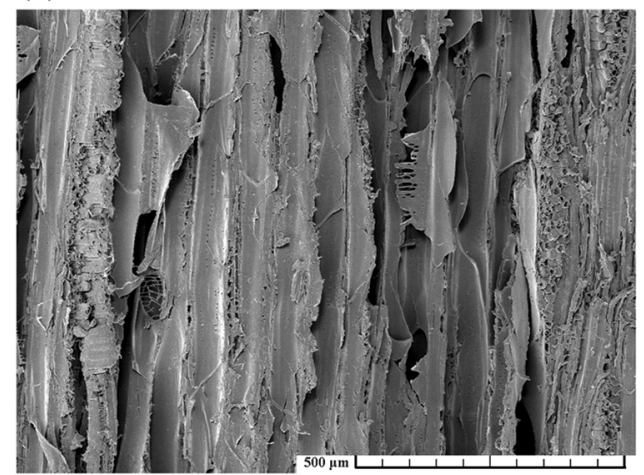

(e)

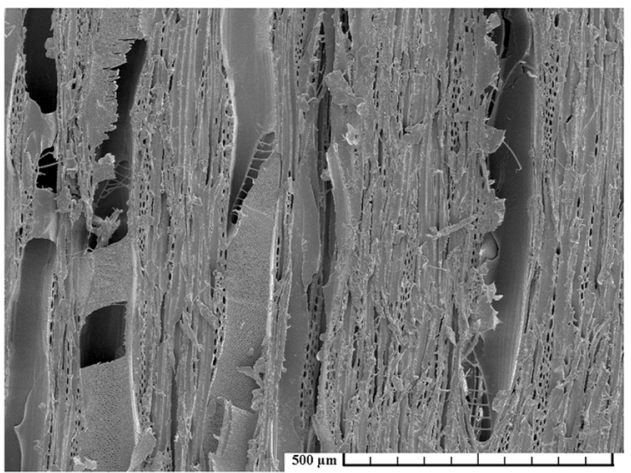

(g)

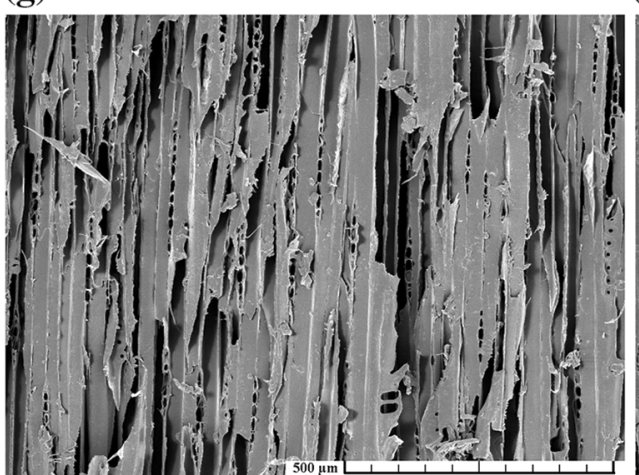

(b)

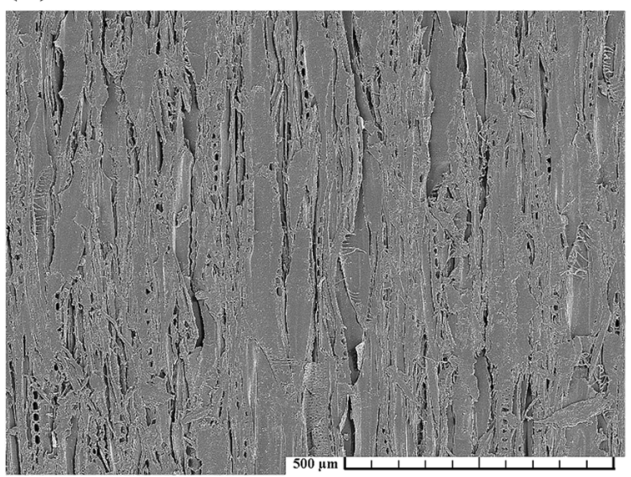

(d)

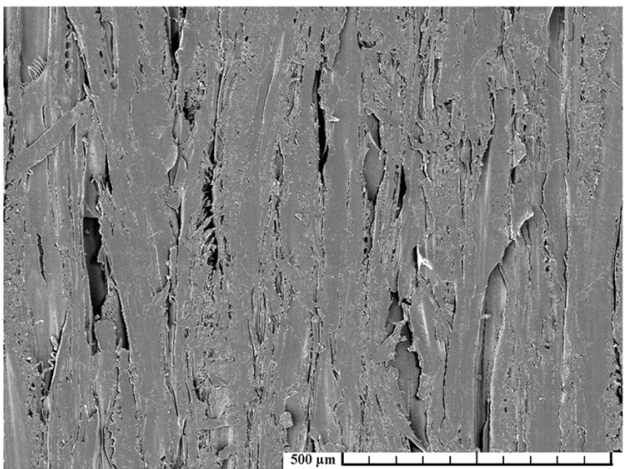

(f)

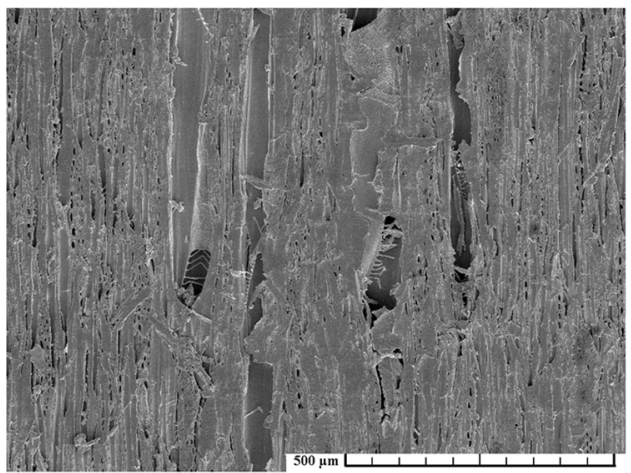

(h)

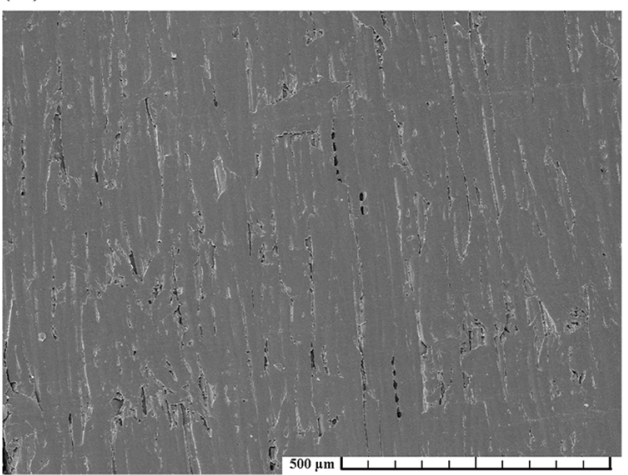

surfaces. Surfaces of the densified samples were much smoother than those of the non-densified samples. The initial roughness of the samples may play an important role affecting gloss of wood veneers. Smaller roughness values correspond to higher gloss values. As it follows from the gloss data, $60^{\circ}$ could be chosen as the measurement 
Fig. 3 Relationship between glosses measured along and across the grain in densified birch veneer

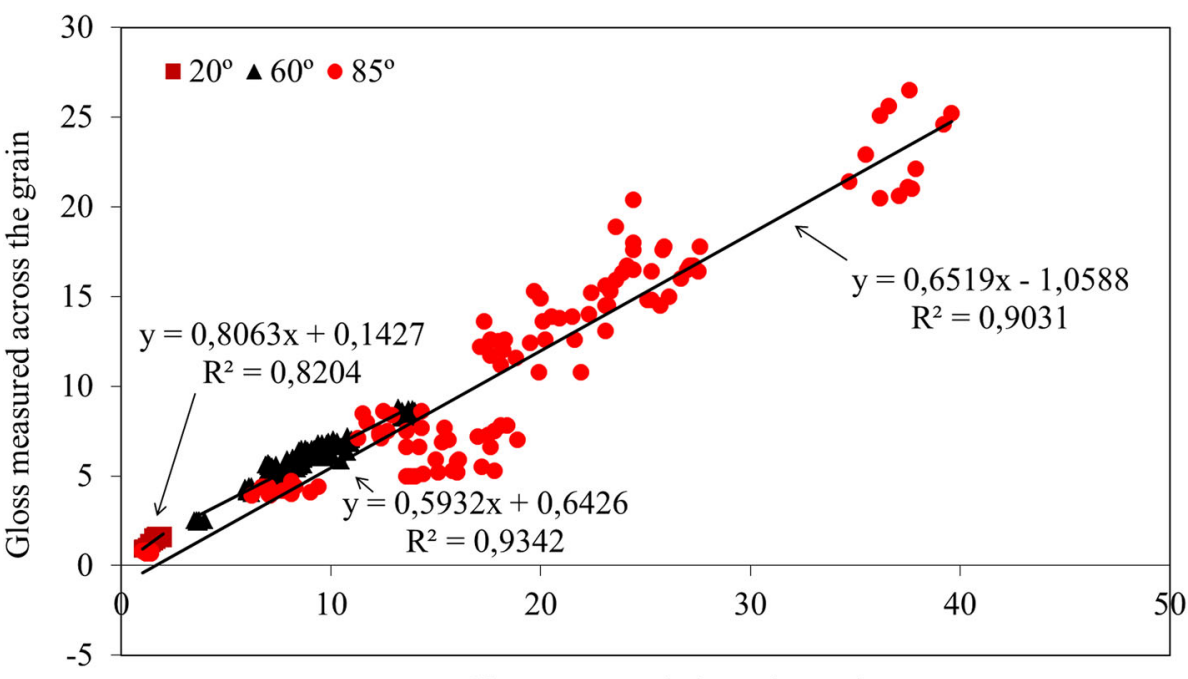

Gloss measured along the grain configuration for non-densified wood in order to better highlight gloss changes, since both $20^{\circ}$ and $85^{\circ}$ setups show gloss values too low in the case of non-densified samples. In turn, angles of $60^{\circ}$ or $85^{\circ}$ could be selected as the measurement configuration of gloss for densified wood.

A typical finding for gloss measurements for all investigated wood species is that gloss values when measured along the grain are higher than those measured across the grain (Table 1). This can be explained by the anatomical structure and irregularities on the surface of wood veneers. Surface roughness more significantly affects scattering of light when measuring gloss across the grain. This leads to greater light scattering, increasing the diffuse component. Actually the differences between the two directions of measurements are appreciable only by considering gloss measurements at any of the tested angles $\left(20^{\circ}, 60^{\circ}\right.$ and $85^{\circ}$ ). It was possible to observe through regression analysis that there is a clear correlation $\left(\mathrm{R}^{2}=0.82-0.93\right)$ between gloss measurements along and across the grain (Fig. 3). Therefore, in practice it is enough to measure gloss along the grain.

Possible correlations between gloss measured at different angles of incident light were also investigated. Some of these correlations for birch veneer are presented in Fig. 4. The high values of the coefficients of determination $\left(\mathrm{R}^{2}=0.82-0.94\right.$ for gloss values obtained along the grain and $\mathrm{R}^{2}=0.75-0.85$ for gloss values obtained across the grain) show a good linear correlation between gloss measured at $60^{\circ}$ and $85^{\circ}$ for all investigated wood species. A less specific correlation exists between gloss measured at $20^{\circ}$ and $60^{\circ}$ (with coefficients of determination 0.58-0.65 for gloss values recorded both along and across the grain) or between $20^{\circ}$ and $85^{\circ}$ (with coefficients of determination
$0.38-0.50$ for gloss values obtained along the grain and $0.28-0.43$ for gloss values obtained across the grain) for alder, birch and pine wood. No correlation was found between gloss measured at $20^{\circ}$ and $60^{\circ}$ or $20^{\circ}$ and $85^{\circ}$ for beech wood. At the moment it is difficult to explain this fact. Perhaps it is due to anatomical features of beech wood compared to the other investigated wood species. Therefore, further studies are needed to explain this phenomenon.

The results of multivariate ANOVA for gloss indicate that the factors and the factor interactions were meaningful at a significance level of $\alpha=0.05$. The results of Duncan's tests conducted to determine the significance of effects of wood species, densification temperature and pressure on surface gloss are given in Table 3. The differences in gloss among all four wood species were statistically significant, ranking from highest to lowest as pine, birch, alder and beech. The higher gloss of pine may be a result of the darker surface and lower roughness compared with the other wood species investigated (Fig. 2). The effect of densification temperature on gloss was statistically significant with the highest value obtained at a temperature $200{ }^{\circ} \mathrm{C}$ and the lowest for non-densified (control) samples. The effect of densification pressure on gloss was also statistically significant with the highest value recorded at $12 \mathrm{MPa}$ and the lowest for non-densified (control) samples.

Gloss is higher after thermo-mechanical densification. Such trends were observed for all four investigated wood species. These findings differ from those obtained in previous studies (Aksoy et al. 2011; Cakicier et al. 2011b; Korkut et al. 2013). This can be explained by the fact that in contrast to previous studies where only heat treatment of wood was applied, in this study heat treatment was 
Fig. 4 Relationship between glosses measured at different angles along (a) and across

(b) the grain in densified birch veneer
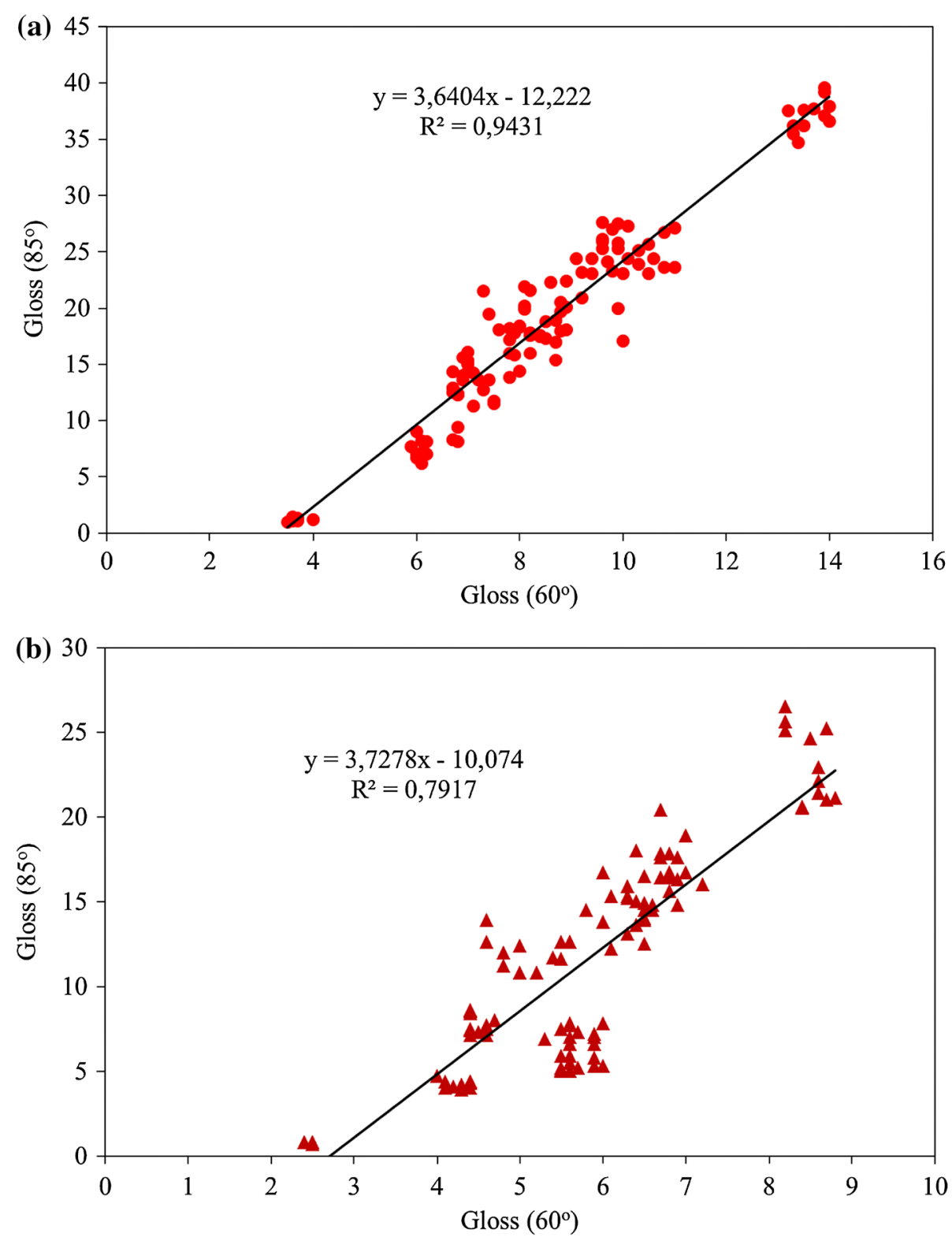

combined with densification. Moreover, the actual densification at high temperature and pressure makes the surface of densified wood smoother and glossier.

\section{Conclusion}

Aesthetic properties of different thermo-mechanically densified wood species (hardwood and softwood) were quantified by gloss measurements. Short-term thermo-mechanical densification improves attractiveness of wood surface. For all the investigated wood species densification induces a strong increase of gloss. This facilitates the application of transparent organic coatings that allow improved natural characteristics of wood to remain visible, and so the demand for them has been increasing. According to the obtained results, with increasing densification temperature and pressure gloss of all the investigated wood species increased significantly. All these variations are more pronounced at higher densification temperatures and pressures. Wood species also have a significant effect on gloss changes.

The natural characteristics of various wood species have an influence on surface characteristics of densified wood veneers such as surface roughness and gloss. ESEM observations show that surfaces of the densified samples were much smoother than those of the non-densified samples. From the obtained findings it appears that higher gloss corresponds to smaller surface roughness.

It is a reasonable solution to use a $60^{\circ}$ or $85^{\circ}$ angle of incidence for both matt and glossy layers in test 
Table 3 Duncan test results for main effects

\begin{tabular}{|c|c|c|c|c|c|c|c|c|c|c|c|c|}
\hline & \multicolumn{12}{|l|}{ Gloss } \\
\hline & \multicolumn{6}{|c|}{ Along the grain } & \multicolumn{6}{|c|}{ Across the grain } \\
\hline & \multicolumn{2}{|l|}{$20^{\circ}$} & \multicolumn{2}{|l|}{$60^{\circ}$} & \multicolumn{2}{|l|}{$85^{\circ}$} & \multicolumn{2}{|l|}{$20^{\circ}$} & \multicolumn{2}{|l|}{$60^{\circ}$} & \multicolumn{2}{|l|}{$85^{\circ}$} \\
\hline & Mean & $\mathrm{SG}$ & Mean & SG & Mean & SG & Mean & SG & Mean & SG & Mean & SG \\
\hline \multicolumn{13}{|c|}{ Wood species } \\
\hline Alder & 1.325 & $b$ & 7.441 & $b$ & 17.481 & $b$ & 1.217 & $b$ & 5.193 & $b$ & 10.403 & $b$ \\
\hline Beech & 1.006 & $a$ & 4.911 & $a$ & 11.430 & $a$ & 0.967 & $a$ & 3.664 & $a$ & 6.477 & $a$ \\
\hline Birch & 1.550 & $c$ & 8.329 & $c$ & 18.099 & $b$ & 1.392 & $c$ & 5.583 & $c$ & 10.739 & $b$ \\
\hline Pine & 1.849 & $d$ & 11.236 & $d$ & 23.629 & $c$ & 1.704 & $d$ & 7.803 & $d$ & 16.085 & $c$ \\
\hline \multicolumn{13}{|c|}{ Temperature } \\
\hline Control & 1.167 & $a$ & 4.417 & $a$ & 1.608 & $a$ & 1.067 & $a$ & 2.902 & $a$ & 0.935 & $a$ \\
\hline $100^{\circ} \mathrm{C}$ & 1.435 & $b$ & 6.930 & $b$ & 13.192 & $b$ & 1.322 & $b$ & 5.106 & $b$ & 6.143 & $b$ \\
\hline $150{ }^{\circ} \mathrm{C}$ & 1.444 & $b$ & 8.170 & $c$ & 18.399 & $c$ & 1.335 & $b$ & 5.670 & $c$ & 11.324 & $c$ \\
\hline $200{ }^{\circ} \mathrm{C}$ & 1.506 & $b$ & 10.025 & $d$ & 26.738 & $d$ & 1.387 & $b$ & 6.794 & $d$ & 18.640 & $d$ \\
\hline \multicolumn{13}{|l|}{ Pressure } \\
\hline Control & 1.167 & $a$ & 4.417 & $a$ & 1.608 & $a$ & 1.067 & $a$ & 2.902 & $a$ & 0.935 & $a$ \\
\hline $4 \mathrm{MPa}$ & 1.340 & $b$ & 7.007 & $b$ & 15.005 & $b$ & 1.222 & $b$ & 4.806 & $b$ & 8.770 & $b$ \\
\hline $8 \mathrm{MPa}$ & 1.463 & $c$ & 8.638 & $c$ & 20.132 & $c$ & 1.351 & $c$ & 6.021 & $c$ & 12.809 & $c$ \\
\hline $12 \mathrm{MPa}$ & 1.583 & $d$ & 9.480 & $d$ & 23.193 & $d$ & 1.471 & $d$ & 6.743 & $d$ & 14.528 & $c$ \\
\hline
\end{tabular}

Different letters denote a statistically significant difference

$S G$ statistical group

measurements. When gloss is measured at a small angle $\left(20^{\circ}\right)$ of incidence, it is impossible to distinguish minor surface roughness, since such surfaces appear equally smooth (the light beam glides over the surface).

Evidently, the high gloss was due to sample preparation by short-term thermo-mechanical densification and changes of color and roughness, which were not considered as variables in this study and will be the subject of further research. Further research is also needed to establish the quantitative relationships between color, roughness and gloss of densified wood.

Acknowledgments The authors would like to thank the COST Action FP 1006 "Bringing new functions to wood through surface modification" for financial support within the framework of the Short Term Scientific Mission (STSM). Thanks to Dr. M. Mamonova for technical assistance in this study by preparing SEM images of nondensified and densified wood samples.

Open Access This article is distributed under the terms of the Creative Commons Attribution License which permits any use, distribution, and reproduction in any medium, provided the original author(s) and the source are credited.

\section{References}

Akgul M, Korkut S (2012) The effect of heat treatment on some chemical properties and colour in Scots pine and Uludag fir wood. Int J Phys Sci 7(21):2854-2859
Aksoy A, Deveci M, Baysal E, Toker H (2011) Colour and gloss changes of Scots pine after heat modification. Wood Res 56(3):329-336

ASTM D523 (1995) Standard test method for specular gloss. American Society for Testing and Materials, West Conshohocken

Bekhta P, Niemz P (2003) Effect of high temperature on the change in colour, dimensional stability and mechanical properties of spruce wood. Holzforschung 57:539-546

Bekhta P, Niemz P, Sedliacik J (2012) Effect of pre-pressing of veneer on the glueability and properties of veneer-based products. Eur J Wood Wood Prod 70:99-106

Cakicier N, Korkut S, Korkut DS, Kurtoglu A, Sönmez A (2011a) Effects of QUV accelerated aging on surface hardness, surface roughness, glossiness, and color difference for some wood species. Int J Phys Sci 6(8):1929-1939

Cakicier N, Korkut S, Korkut DS (2011b) Varnish layer hardness, scratch resistance, and glossiness of various wood species as affected by heat treatment. BioResources 6(2):1648-1658

Candan Z, Hiziroglu S, McDonald AG (2010) Surface quality of thermally compressed Douglas fir veneer. Mater Des 31:3574-3577

Candan Z, Korkut S, Unsal O (2013) Thermally compressed poplar wood (TCW): physical and mechanical properties. Drvna Industrija 54(2):107-111

Demirci Z, Sönmez A, Budakci M (2013) Effect of thermal ageing on the gloss and the adhesion strength of the wood varnish layers. BioResources 8(2):1852-1867

DIN 67530: 1982. Reflectometer as a means for gloss assessment of plane surfaces of paint coatings and plastics

Diouf PN, Stevanovic T, Cloutier A, Fang C-H, Blanchet P, Koubaa A, Mariotti N (2011) Effects of thermo-hygro-mechanical densification on the surface characteristics of trembling aspen and hybrid poplar wood veneers. Appl Surf Sci 257:3558-3564 
Dundar T, Akbulut T, Korkut S (2008) The effects of some manufacturing factors on surface roughness of sliced Makoré (Tieghemella heckelii Pierre Ex A.Chev.) and rotary-cut beech (Fagus orientalis L.) veneers. Build Environ 43:469-474

Fang C-H, Mariotti N, Cloutier A, Koubaa A, Blanchet P (2012) Densification of wood veneers by compression combined with heat and steam. Eur J Wood Wood Prod 70(1-3):155-163

Goktas O, Toker H (2010) Effects of the traditional Turkish art of marbling (Ebru) techniques on the adhesion, hardness, and gloss of some finishing varnishes. Forest Prod J 60(7/8):648-653

Gonzalez-Pena MM, Hale MDC (2009) Colour in thermally modified wood of beech, Norway spruce and Scots pine. Part 1: colour evolution and colour changes. Holzforschung 63:385-393

ISO 2813: 1994. Paints and varnishes-Determination of specular gloss of non-metallic paint films at $20^{\circ}, 60^{\circ}$ and $85^{\circ}$

Kamke FA (2006) Densified radiate pine for structural composites. Maderas Ciencia y Tecnologia 8(2):83-92

Kato H, Masuda M (1989) Anisotropic gloss of wood and light reflection at the surface of lumen. Bull Kyoto Univ For 61:292-300

Korkut DS, Hiziroglu S, Aytin A (2013) Effect of heat treatment on surface characteristics of wild cherry wood. BioResources $8(2): 1582-1590$

Kutnar A, Šernek M (2007) Densification of wood. Zbornik gozdarstva in lesarstva 82:53-62

Masuda M, Kato H, Horio Y (1989) Relation between properties of mechanically processed surfaces of wood and the gloss images. Bull Kyoto Univ For 61:301-309

Militz H (2002) Thermal treatment of wood: European processes and their background. IRG/WP 02-40241

Nakamura M, Masuda M, Shinohra K (1999) Multiresolutional image analysis of wood and other materials. J Wood Sci 45:10-18
Navi P, Girardet F (2000) Effects of thermo-hydro-mechanical treatment on the structure and properties of wood. Holzforschung 54(3):287-293

Navi P, Sandberg D (2012) Thermo-hydro-mechanical processing of wood. EPEL Press, Lausanne

Scrinzi E, Rossi S, Deflorian F, Zanella C (2011) Evaluation of aesthetic durability of waterborne polyurethane coatings applied on wood for interior applications. Prog Org Coat 72:81-87

Shaoping D, Hanxian C, Jinchun L (2010) Effects of high temperature heat treatment on the color and painting properties of Chinese fir plantation wood. J Fujian Agric For Univ 39(5):484-489

Simsek H, Baysal E (2012) An investigation on colour and gloss changes of wood impregnated with borates. Wood Res 57(2):271-277

Sönmez A, Budakci M, Yakin M (2004) Effect of application methods on the hardness gloss and adhesion strength of waterborne varnish coating on the wooden surface. J Polytech 7(3):229-235

Sundqvist B (2002) Color response of Scots pine (Pinus sylvestris), Norway spruce (Picea abies) and birch (Betula pubescens) subjected to heat treatment in capillary phase. Holz Roh- Werkst 60(2):106-114

Tarkow H, Seborg RM (1968) Surface densification of wood. Forest Prod. J. 18(9):104-107

Welzbacher CR, Wehsener J, Rapp AO, Haller P (2008) Thermomechanical densification combined with thermal modification of Norway spruce (Picea abies Karst) in industrial scale-dimensional stability and durability aspects. Holz Roh- Werkst 66:39-49

Wood handbook-Wood as an engineering material (2010) General Technical Report FPL-GTR-190. Madison, WI: U.S. Department of Agriculture, Forest Service, Forest Products Laboratory. 508 p 